\title{
The Future of Involuntary Sovereign Debt Restructurings: \\ Mamatas and Others v. Greece and the Protection of Holdings of Sovereign \\ Debt Instruments under the ECHR
}

\section{By Astrid Iversen ${ }^{1}$}

\begin{abstract}
This article revisits Greece's 2012 debt restructuring, focusing on the legal changes and litigation that arose in relation to it in order to shed light on what kind of restructuring we may see next, in both Greece and the larger euro area. It particular, creditor protection under the European Convention of Human Rights (ECHR) in sovereign debt restructuring by a debtor state retroactively changing the debt instrument's background law is discussed in light of Mamatas and Others v. Greecece. This case provides a legal starting point for considering whether and when it is acceptable under the ECHR to interfere with private property in involuntary debt restructuring enabled by amendments of the law of the debtor state. The case also invites a more general discussion of the crisis resolution tools used in the Greek restructuring, which were the majority modification procedures, often referred to as collective action clauses (CACs) when found in debt instruments. This article argues that the implementation of CACs in sovereign bonds may decrease the need for involuntary crisis resolution measures. An examination of the design and prevalence of CACs shows, however, that these contractual clauses have limitations and cannot guarantee successful restructurings in all situations. The article concludes that if sovereign debt restructurings are to serve as a viable crisis resolution measure - even if only as a last resort - reform of the current legal framework is needed.
\end{abstract}

\section{Keywords}

Collective action clauses, European Convention of Human Rights, Greece, protection of property, sovereign debt restructuring, unilateral change of contract, retroactive legislation.

\footnotetext{
${ }^{1}$ Research fellow at the Department of Private Law, University of Oslo, Norway. The author would like to express gratitude towards Sebastian Grund, Prof. Mads Andenas and the anonymous reviewers for insightful comments during the writing process. The usual disclaimers apply.
} 


\section{Table of Contents}

I. INTRODUCTION

II. COLLECTIVE ACTION PROBLEMS IN SOVEREIGN DEBT RESTRUCTURING... 5

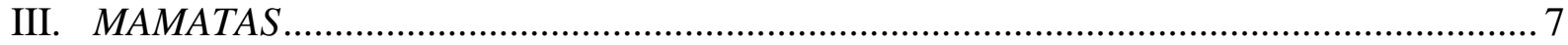

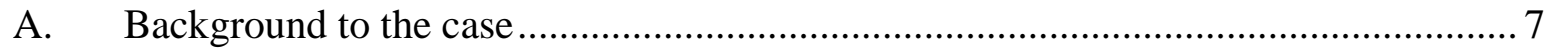

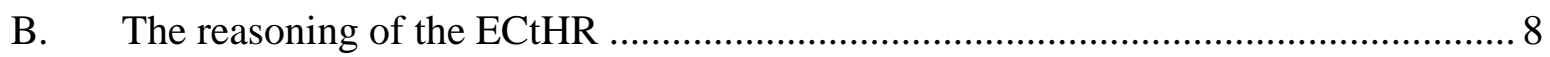

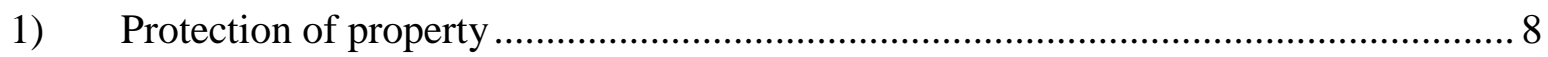

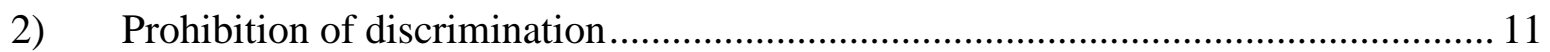

IV. THE FUTURE OF INVOLUNTARY SOVEREIGN DEBT RESTRUCTURINGS ...... 13

A. The impact of Mamatas on future involuntary crisis resolution measures ............... 13

1) Future crisis resolution measures in the euro area............................................. 13

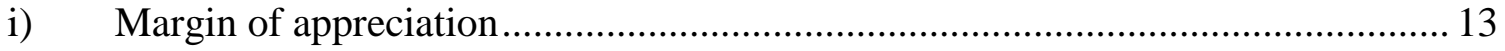

ii) Legitimate expectations, valuation of losses and risk taking ............................... 15

iii) Legislative implementation of class voting in times of CACs ............................ 17

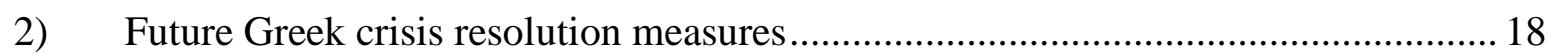

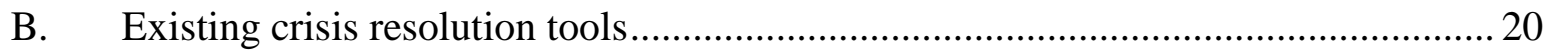

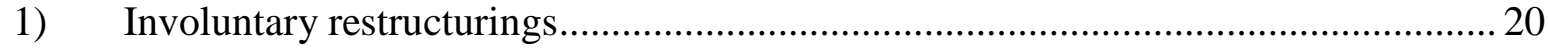

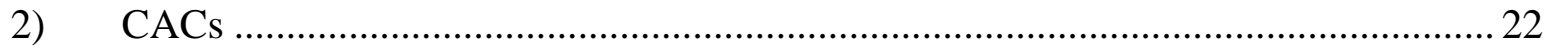

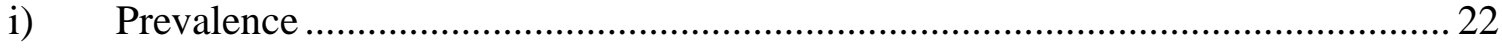

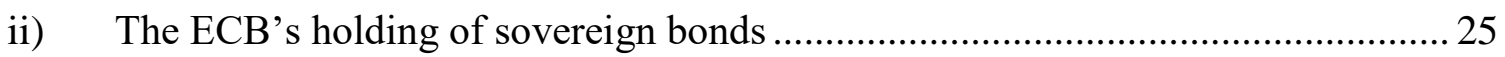

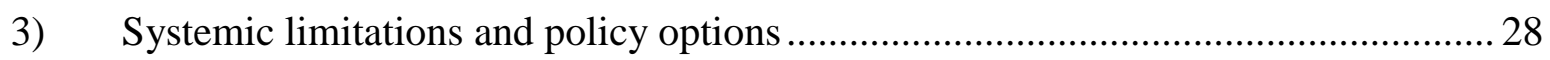

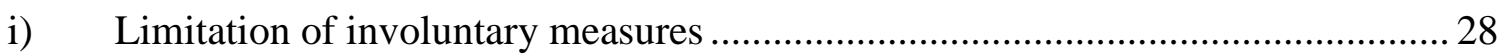

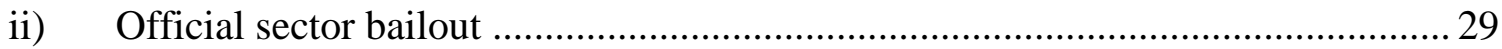

C. Global discussions of sovereign debt crisis resolution reforms .............................. 30

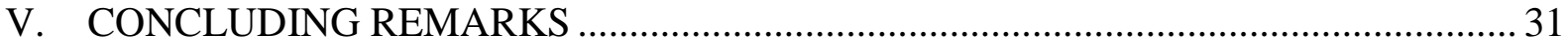




\section{INTRODUCTION}

There are no national or international legal frameworks regulating sovereign insolvency. To ease its debt burden, a state has to renegotiate its debt contracts with its various creditors. However, various legal tools may be used to ease the renegotiation process. One heavily debated tool is for the debtor state to change its laws, thereby retroactively and unilaterally changing the terms of the debt instrument regulated by the laws of said state - an involuntary restructuring.

Greece used this tool in 2012 to enable a sorely needed sovereign debt restructuring. In October 2009, Greece entered a deep economic crisis. ${ }^{2}$ In 2010, it was granted crisis loans from the International Monetary Fund (IMF) and euro area governments, but it soon became apparent that to improve its economic situation, the state also had to seek debt relief through a renegotiation of its outstanding sovereign bonds. ${ }^{3}$ Because it was difficult to get all the creditors holding Greek sovereign bonds to voluntarily accept a cut in the value of their bonds, Greece adopted a law that retroactively implemented majority voting procedures for all sovereign bonds subject to Greek law. ${ }^{4}$ This voting procedure allows for a supermajority of creditors to approve restructuring terms and bind dissenting minority bondholders, including amendments that exchange an existing bond with new bonds of a lower value.

A set of creditors brought a case against Greece to the European Court of Human Rights (ECtHR). The legal question at stake was whether this involuntary bond exchange, leading to a 53.5 percent loss in the nominal value of the bonds, constituted a violation of the bondholders' rights to protection of their property pursuant to Article $1,1^{\text {st }}$ Protocol to the European Convention on Human Rights (hereafter 'the Convention' or 'ECHR'). Additionally, the Court considered whether the crisis measures constituted a breach of the prohibition of discrimination pursuant to Article 14 of the Convention, in conjunction with Article $1,1^{\text {st }}$ Protocol to the Convention.

First, this article analyses this case, Mamatas and Others v. Greece, to shed light on what type of involuntary crisis resolution measures we may see in the future. ${ }^{5}$ It discusses what types of

\footnotetext{
${ }^{2}$ Zettelmeyer, Trebesch, Gulati, 'The Greek debt restructuring: an autopsy' (2013) 28 Economic Policy 513, 4 ${ }^{3}$ Ibid

${ }^{4}$ Mamatas and others $v$ Greece App no 63066/14 (ECHR, 21 July 2016), § 99. See section II for discussion about collective action problems and collective action clauses.

${ }^{5}$ Mamatas and others v Greece App no 63066/14 (ECHR, 21 July 2016).
} 
involuntary restructuring a government may implement in times of crisis and what level of protection must be offered to sovereign bondholders under the ECHR.

Second, this study discusses the specific crisis resolution measures applied by Greece, namely the majority voting procedure. Such voting procedures can also take the form of a contract clause in a debt instrument, known as collective action clauses (CACs). CACs include a range of contract clauses, also found in sovereign bonds, that seek to coordinate bondholder action to ensure efficient restructurings. ${ }^{6}$ The most central of these is the majority action clause, which allows for a supermajority of creditors to approve restructuring terms and bind dissenting minority bondholders. Currently, the majority of international finance institutions and governments rely on CACs to enable successful debt restructurings. Based on the Mamatas case, this article examines the interrelationship between the functioning of the different tools: involuntary restructurings based on amendments of the law of the debtor state (local law) and the operation of CACs. It investigates whether the implementation of CACs in sovereign bonds decreases the need for involuntary crisis resolution measures, making sovereign debt restructuring more predictable for the actors involved. To a large extent, the effectiveness and prevalence of existing CACs will determine whether future sovereign bond restructurings will require involuntary measures.

There is an ongoing discussion in Europe concerning a euro area reform. ${ }^{7}$ This article makes a small contribution to this debate by addressing whether the existing crisis resolution tools allow restructuring to serve as a viable alternative to official crisis loans.

In this study, situations in which the debtor state changes its laws, thereby retroactively and unilaterally changing the terms of the debt instruments regulated by the laws of said state, are referred to as 'forced' or 'involuntary' restructurings. In both legal and economic research, especially in relation to the 2012 Greek restructuring, this situation is often referred to as a 'voluntary restructuring, ${ }^{8}$ When labelling a restructuring forced or voluntary, such studies have typically emphasised a broader range of factors related to the negotiation of the restructuring

\footnotetext{
${ }^{6}$ Rodrigo Olivares-Caminal, Legal aspects of sovereign debt restructuring (Sweet \& Maxwell, 2009) 111.

${ }^{7}$ See for example CEPR Policy Portal for research based policy analysis and commentary from leading economists: https://voxeu.org/debates/euro-area-reform

${ }^{8}$ See for example the term used in Zettelmeyer, Trebesch, Gulati, 'The Greek debt restructuring: an autopsy' (2013) 28 Economic Policy 513.
} 
terms, including the extent to which various creditors have been consulted by or have negotiated with the debtor state and how other relevant parties, such as the IMF, the ECB, or other key institutions, were involved in the negotiation of the restructuring terms and supported the outcome. In a situation like a debt restructuring, in which legal rules determine the outcome only to a limited extent, such a subjective definition may be appropriate. However, the treatment of a creditor (or another involved actor) in a restructuring, as well as whether it is satisfied with the outcome, is likely to influence whether a particular restructuring is labelled involuntary or voluntary. For example, the creditors who voted against the Greek restructuring, but who were forced to participate due to the retroactively implemented legislation, are likely to label the restructuring involuntary. For these reasons, this article defines a restructuring as involuntary when it is enabled by unilateral changes to the bond terms by means of the debtor state amending the background law of the debt instrument, thus applying a more legalistic approach.

This article proceeds as follows. Section II gives a brief account of the general challenges associated with sovereign debt restructuring, commonly referred to as collective action problems. Section III presents the Mamatas case, the background to the case, and the Court's consideration of whether there was illegal interference with the investors' right to property and whether the debt restructuring discriminated against the minority creditors. The subsequent section discusses how the Mamatas case may influence the future of involuntary debt crisis resolutions in Greece and in euro area countries more generally. Section IV also discusses the efficiency of existing crisis resolution tools, more specifically CACs, and how they may influence the need for involuntary measures in the future, and it briefly investigates potential initiatives to reform the current framework of sovereign debt restructuring. Section V summarises the main findings and offers some concluding remarks.

\section{COLLECTIVE ACTION PROBLEMS IN SOVEREIGN DEBT RESTRUCTURING}

Greece is not the first (nor will it be the last) country to experience a sovereign debt crisis and face challenges when implementing crisis resolution measures. ${ }^{9}$ Sovereign debt crises have occurred regularly throughout history, and the restructuring of sovereign debt is a relatively common crisis resolution measure. There is no universally accepted definition of a sovereign debt restructuring, but it can be defined as an exchange of outstanding debt instruments, such

\footnotetext{
${ }^{9}$ For a thorough presentation of sovereign defaults and restructurings between 1950 and 2010, see Das, Papaioannou, Trebesch, 'Sovereign Debt Restructurings 1950-2010: Literature Survey, Data, and Stylized Facts' (2012) IMF Working Paper 12/203.
} 
as loans or bonds, for new debt instruments or cash through a formal process. Such renegotiation may include prolonging the maturity, reducing the interest rate or even cutting the nominal value of the debt. ${ }^{10}$ There is no international or national insolvency framework dealing with states in sovereign debt crises. Restructuring requires unanimity amongst the contracting parties, unless the contract or the background law states otherwise. It can therefore be challenging to reach an agreement. One of the main difficulties is the so-called collective action problem. Even if it is in the best interests of the creditors as a group to agree to a restructuring as quickly as possible, individual creditors may be incentivised not to participate (to 'hold out') in the hope of recovering full payment on the contractual claim. In this way, minority creditors may free ride on co-creditors, letting them take the loss of a haircut. If the holdout risk is perceived as significant, creditors who would otherwise be willing to participate in a restructuring may be reluctant to do so, especially when they know co-creditors will be repaid more if they hold out. Full payment of holdout creditors also reduces the sovereign debtor's available resources to pay the restructured creditors, which further decreases the incentive to participate in a restructuring. Another challenge of the restructuring process is related to the rapid rise in bond financing in both external and domestic sovereign debt markets. There are often several thousand (if not hundreds of thousands of) creditors holding the same type of bond and residing in different jurisdictions. The sheer number of creditors who need to communicate and coordinate their interests and actions contributes to the difficulty of reaching a restructuring agreement.

When they seek to restructure their sovereign debt, all sovereign debtors face the challenge of coordinating the actions of bondholders to ensure that they act in the common interest of all creditors and minimise the overall losses entailed in the debt crisis resolution. The current system of sovereign debt restructuring is highly fragmented and has not managed to tackle these challenges. This has resulted in several inefficiencies. It is now acknowledged that debt restructurings have often included 'too little' debt and have come 'too late', thus failing to reestablish debt sustainability and market access in a durable way. ${ }^{11}$

\footnotetext{
10 Das, Papaioannou, Trebesch, 'Sovereign Debt Restructurings 1950-2010: Literature Survey, Data, and Stylized Facts' (2012) IMF Working Paper 12/203, 7.

${ }^{11}$ IMF, Sovereign Debt Restructuring - Recent Developments and Implications for the Fund's Legal and Policy Framework, (IMF Staff Report, 2013) 15.
} 
These problems associated with collective action demonstrate the need for legal tools that incentivise or force creditors to participate in a sovereign debt restructuring. At least, such tools are needed if one wants sovereign debt restructuring to be a viable debt crisis resolution tool, even if only as a measure of last resort. One such tool is the use of involuntary debt restructuring based on amendments of the law of the debtor country.

\section{MAMATAS}

\section{A. Background to the case}

In October 2009, Greece found itself in a deep economic crisis. ${ }^{12}$ In 2010, the state was no longer able to borrow on the capital markets and was forced to borrow from the IMF and various euro area states. Additionally, hoping to resolve its debt crisis, Greece sought to renegotiate its loan contracts with its creditors in order to ease the payment terms and reduce its public debt. The euro area and the IMF made future support conditional on Greece obtaining a debt reduction from the private sector, meaning holders of sovereign bonds, of at least 50 percent. ${ }^{13}$ This is commonly referred to as private sector involvement. ${ }^{14}$

In February 2012, the Greek Parliament enacted law no. 4050/2012 - known as the Greek Bondholder Act. ${ }^{15}$ The act aimed to involve all of Greece's private creditors in the debt restructuring and implemented a voting procedure that allows for a supermajority of creditors to approve restructuring terms and bind dissenting minority bondholders, including amendments that exchange an existing bond with new bonds of a lower value. The Greek Bondholder Act has the same function as a CAC, which is a contract provision found to an increasing extent in sovereign bonds. Without this act, the Greek bonds could have been restructured only with the unanimous consent of all bondholders. The implementation of the majority voting procedure ensured that the bondholders who did not wish to participate in the restructuring operation would nevertheless be bound, provided that at least two-thirds of the individual bondholders accepted the restructuring agreement. The Greek government managed to achieve this majority, mainly through the participation of institutional investors such as banks, and the old bonds were exchanged for new ones with a 53.5 percent lower nominal value

\footnotetext{
${ }^{12}$ Zettelmeyer, Trebesch, Gulati, 'The Greek debt restructuring: an autopsy’ (2013) 28 Economic Policy 513, 4.

${ }^{13}$ Mamatas and others $v$ Greece App no 63066/14 (ECHR, 21 July 2016), §§ 11 and 102.

${ }^{14} \mathrm{https}$ ://www.esm.europa.eu/content/what-was-private-sector-involvement-psi-greece

${ }^{15}$ Law no. 4050/2012 'Rules of amendment of titles issues or guaranteed by the Hellenic Republic with the Bondholder's agreement' (Government Gazette A' 36/23.02.2012 of the Hellenic Republic). See Mamatas and others $v$ Greece App no 63066/14 (ECHR, 21 July 2016) § 99.
} 
(a decrease of around 75 percent in net present value terms). In total, the restructuring of the debt covered 91.05 percent of the outstanding receivables. ${ }^{16}$

Some of the bondholders who had been forced to participate in the bond exchange lodged an action with the Court of Cassation to set aside the decision, arguing that the forced exchange of bonds violated their right to protection of property. The action was dismissed by the plenary Supreme Administrative Court, and the case was thereafter submitted to the ECtHR. ${ }^{17}$

\section{B. The reasoning of the ECtHR}

The ECtHR held, unanimously, that Greece had not violated the right to protection of property pursuant to Article 1, $1^{\text {st }}$ Protocol to the ECHR, or the right to nondiscrimination pursuant to Article 14 of the Convention, in conjunction with Article 1, $1^{\text {st }}$ Protocol to the ECHR.

\section{1) Protection of property}

The ECtHR started by confirming that holding sovereign bonds falls within the meaning of 'possession' in the first sentence of Article 1, $1^{\text {st }}$ Protocol. ${ }^{18}$ The Court noted that the government bonds were traded on the capital market, where their value fluctuates. However, as the bonds mature, their nominal value must in principle be repaid. According to the terms of the Greek bond, the holders were entitled to repayment at maturity, and hence the bonds constituted a possession. ${ }^{19}$

The Bondholder Act enabled the forced participation in the bond exchange of bondholders who did not wish to participate in the restructuring ('holdout creditors'), and it resulted in a 53.5 percent decrease in the nominal value of their bonds. The Court shared the applicants' view that

\footnotetext{
${ }^{16}$ Markakis, 'European Court of Human Rights Rules on Greek Debt Restructuring' (OxHRH Blog, 31 July 2016) <http://ohrh.law.ox.ac.uk/european-court-of-human-rights-rules-on-greek-debt-restructuring/> Accessed 03.09.2016.

${ }^{17}$ Bondholders also brought cases in Austrian and German courts and before the International Centre for Settlement of Investment Disputes. For an overview of litigation following the Greek restructuring, see Sebastian Grund, 'Restructuring government debt under local law: the Greek case and implications for investor protection in Europe' (2017) 12 Capital Markets Law Journal 253.

${ }^{18}$ Mamatas and others $v$ Greece App no 63066/14 (ECHR, 21 July 2016), § 90. According to ECtHR jurisprudence, there are two broad categories of 'possessions' pursuant to the first sentence of Art. 1 to Protocol No. 1 of the Convention: existing property rights and existing claims to money or performance with a financial value. See Michael Waibel, Sovereign defaults before international courts and tribunals (Cambridge University Press, 2011) 182. Waibel also underlines that the wide definition of possessions under Article 1 of Protocol No. 1 ECHR is not necessarily co-extensive with the protection of property under general international law, outside the regional European context.
}

${ }^{19}$ Mamatas and others $v$ Greece App no 63066/14 (ECHR, 21 July 2016), § 90. 
this constituted an interference with the bondholders' right to respect for their property pursuant to the first sentence of Article $1,1^{\text {st }}$ Protocol. The question was hence whether this interference was justified. ${ }^{20}$

The Court recalled that any interference by a public authority in the exercise of the right to property must pursue a legitimate aim and that the measures applied must be proportionate to the legitimate aim pursued. This implies that a fair balance must be struck between the general interests of society and the fundamental rights of the individual, so that the burden of the latter is not excessive. ${ }^{21}$

Turning to the facts of the case, the Court established that the interference was clearly prescribed by law and that it pursued a public-interest aim in accordance with the second sentence of Article $1,1^{\text {st }}$ Protocol. ${ }^{22}$ The latter was substantiated by taking into account the seriousness of Greece's economic crisis. In this context, Greece acted legitimately in taking steps to maintain the economic stability of the country and in the general interests of society by seeking a restructuring of public debt. The Court then noted that through the bond exchange operation, Greek authorities had managed to reduce the Greek debt by approximately 107 billion euros (EUR). Moreover, although the interest payments scheduled for 2012 were initially estimated at EUR 17.5 billion, they had dropped to EUR 12.2 billion following the bond exchange and remained under EUR 6 billion in 2013. ${ }^{23}$

In the context of proportionality, the Court noted that the involuntary reduction of value of the bonds by 53.5 percent was not in itself sufficient to establish that the legislative act resulted in the termination of, or an insignificant return on, the bondholders' investment in Greek state bonds. ${ }^{24}$ In the Court's opinion, the reference point for assessing the loss suffered should not be the amount the bondholders hoped to collect at the time of the bond's maturity. The Court indirectly held that it is the true market value at the time of interference with the possession (i.e.

\footnotetext{
${ }^{20}$ Ibid, $\$ 92$.

${ }^{21}$ Ibid, $\S 96$.

22 The Court stated that the interference was prescribed by Law: Law No. 4050/2012, two decisions of the Council of Ministers of 24 February and 9 March 2012, the 9 March 2012 decision of the Deputy Minister for Economic Affairs and the 9 March 2012 decision of the Governor of the Bank of Greece. See Mamatas and others v Greece App no 63066/14 (ECHR, 21 July 2016), § 105.

${ }^{23}$ Mamatas and others $v$ Greece App no 63066/14 (ECHR, 21 July 2016), §103-104.

${ }^{24}$ Ibid, $§ 110$.
} 
the date on which Greece had adopted the impugned regulations) that should be found. ${ }^{25}$ The market value was likely affected by Greece's economic situation, and according to the Court, this situation therefore had to be taken into account when considering the financial gain investors could expect from the bonds. The Court further noted that the fact that the applicants had not agreed to the bond exchange - which was imposed on them through a majority bondholder vote enabled by the Greek Bondholder Act - did not as such affect the assessment of the proportionality of the interference. ${ }^{26}$

In the end, the Court relied on three main arguments when concluding that the interference was proportionate. ${ }^{27}$ First, bondholders who did not want to take part in the bond exchange and feared that the value of their bonds would decrease as a result of the implementation of the majority voting procedure could have sold their bonds on the market up until the time limit mentioned in Greece's bond exchange offer. Second, such majority voting procedures - that is, CACs - represent a common contractual tool on the international money market and not an exceptional means of executing a debt restructuring. ${ }^{28}$ Third, if the Greek Bondholder Act had not been implemented, all the bondholders would have had to reach a consensus, and Greece probably would not have been able to restructure its debts. Had these clauses not been implemented through legislation, the bondholders consenting to the bond exchange would have been forced to take an even larger cut. In this context, the Court concluded that the implementation of the Greek Bondholder Act leading to the subsequent debt restructuring was an appropriate and necessary means of reducing Greek public debt and saving Greece from defaulting on its sovereign debt. ${ }^{29}$

Of key importance to the conclusion is the Court's jurisprudence on the margin of appreciation of states when implementing crisis resolution measures, especially in the context of the 2008 economic crisis in Europe. ${ }^{30}$ The Court recalled that state parties to the convention enjoy a wide margin of appreciation when it comes to determining their social policy. Because the decision

\footnotetext{
${ }^{25}$ Ibid, $\S 112$.

${ }^{26}$ Ibid, $\S 113$.

${ }^{27}$ Ibid, $\$ \S 114-115$.

${ }^{28}$ Since 1 February 2013, CACs have been included in all new euro area government bonds, with a maturity above one year. For the prevalence of CACs in sovereign bonds, see section IV B2.

${ }^{29}$ Mamatas and others $v$ Greece App no 63066/14 (ECHR, 21 July 2016), § 116.

${ }^{30} \mathrm{Ibid}, \S 88$. References are made amongst others to Valkov and others v Bulgaria App No 2033/04 (ECHR, 25 October 2011); Koufaki and ADEDYv Greece App no - 57665/12 and 57657/12 (ECHR, 7 May 2013); Carvalho da Silva Rico v Portugal App no 13341/14 (ECHR, 24 September 2015).
} 
to enact laws to balance state expenditure and revenue will commonly involve consideration of political, economic and social issues, national authorities are in principle - according to the Court's practice - better placed than an international tribunal to choose the most appropriate means of achieving this balance. The Court should therefore not intervene unless the measures prove to be manifestly without reasonable foundation. ${ }^{31}$ This also applied to situations involving controversial legislative schemes that significantly impact the economy of the country, and national authorities have considerable discretion to select not only the measures intended to secure respect for property rights or to regulate ownership relations, but also the appropriate time for their implementation. ${ }^{32}$

In view of the wide margin of appreciation of the Contracting States in the context of economic crisis resolution, the Court held that Greece had not breached the bondholders' right to protection of property pursuant to Article $1,1^{\text {st }}$ Protocol. ${ }^{33}$

\section{2) Prohibition of discrimination}

The Greek bondholders who were forced to participate in the bond exchange also claimed that they had been discriminated against in violation of Article 14 of the Convention in conjunction with Article $1,1^{\text {st }}$ Protocol. The applicants asserted that they were a different type of creditor compared to those voluntarily accepting the restructuring (private individuals, including small investors, usually with capital of less than EUR 100,000), who held bonds with a shorter life

\footnotetext{
${ }^{31}$ Refering to previous cases such as Terazzi S.r.l. v Italy App No 27265/95 (ECHR, 26 October 2004) and Wieczorek v. Poland App no 18176/05 (ECHR, 8 March 2010). The original judgment (French) states: 'La Cour rappelle en outre qu'elle a déjà construit une jurisprudence relative à la marge d'appréciation des États dans le contexte de la crise économique qui sévit en Europe depuis 2008 et plus particulièrement en relation avec des mesures d'austérité prises par voie législative ou autre et visant des couches entières de la population (...) Dans ce contexte, la Cour rappelle aussi que les Etats parties à la Convention jouissent d'une marge d'appréciation assez ample lorsqu'il s'agit de déterminer leur politique sociale. L'adoption des lois pour établir l'équilibre entre les dépenses et les recettes de l'Etat impliquant d'ordinaire un examen de questions politiques, économiques et sociales, la Cour considère que les autorités nationales se trouvent en principe mieux placées qu'un tribunal international pour choisir les moyens les plus appropriés pour parvenir à cette fin et elle respecte leurs choix, sauf s'ils se révèlent manifestement dépourvus de base raisonnable...'. Mamatas and others v Greece App no 63066/14 (ECHR, 21 July 2016), § 88.

32 The court refers to Broniowski v Poland App No 31443/96 (ECHR, 22 June 2004). See Mamatas and others v Greece App no 63066/14 (ECHR, 21 July 2016), § 89. Another case which demonstrated the state's wide margin of appreciation when implementing involuntary crisis resolution measures interfering with private property is Dennis Grainger and others v UK App No 4940/10 (ECHR, 10 July 2012). The case concerned the collapse and nationalization of the British bank Northern Rock. Shareholders of the bank sought to obtain compensation from the UK, but the case was unanimously dismissed by the ECtHR as manifestly ill-founded and inadmissible.

${ }^{33}$ Mamatas and others v Greece App no 63066/14 (ECHR, 21 July 2016), § 120.
} 
expectancy and without the level of professional insight legal entities in the financial market might have. As a result, they argued that they should be treated differently from the bigger institutional creditors. The Court refuted the applicants' arguments.

According to the case law of the ECtHR, the right not to be discriminated against in the enjoyment of rights under the Convention pursuant to Article 14 is also violated if a state does not provide different treatment to persons whose situations are significantly different. In certain circumstances, it is the absence of differential treatment to correct an inequality that may, without a reasonable and objective justification, constitute a violation of the Article. ${ }^{34}$

Applying these considerations to the facts of the case, the Court noted that, even assuming the applicants were right in their allegations of inverted discrimination (i.e. equal treatment of different situations), the design of the restructuring process was justified. ${ }^{35}$ First, the Court explained that it would be difficult to locate the persons who should allegedly receive special treatment and thus be exempted from the bond exchange. This is in part because the Greek economic crisis had resulted in a highly volatile bond market in which sovereign bonds were traded at high frequency, but also because an attempt to locate these bondholders would have led to a prolonged restructuring process that could have amplified the damage to the country's economy. Second, even if the bondholders could have been located, it would have been difficult to draw up specific criteria with which to legitimately differentiate between the types of creditors. The Court found it problematic to draw a distinction between natural and legal persons or between professional and nonprofessional investors, because the rights enshrined in the bond contract did not provide reasons for differentiating between bondholders based on status and gave no guidance regarding what factors should determine different statuses. Further, the Court found it unfair to draw a line between private legal persons and companies, because some private individuals had invested over EUR 100,000 in the relevant bonds, whereas some legal entities and companies had invested less. Third, the Court accepted the argument of the Greek Government that an announcement exempting specific categories of bondholders from

\footnotetext{
${ }^{34}$ See amongst others Thlimmenos v Greece App No 34369/97(ECHR, 6 April 2000); Stec and others $v$ the United Kingdom App No 65900/01 (ECHR, 12 April 2006). The Court also highlighted the fact that general policy measures that have disproportionately prejudicial effects on a group of people can be considered discriminatory even if they do not specifically target this group and there is no discriminatory intent. It is the Government who has the burden of proof when proving that differential treatment was justified. See Mamatas and others v Greece App no 63066/14 (ECHR, 21 July 2016), § 130-132.

${ }^{35}$ Ibid, § 135-139.
} 
restructuring would likely lead to a massive transfer of bonds to the exempted categories. Consequently, the holders of nonexempted bonds would have had to take a much more drastic haircut to achieve the same reduction in public debt, which might have jeopardised the entire restructuring agreement. Lastly, and more generally, the Court acknowledged Greece's need to maintain momentum in the restructuring operation and to act quickly.

Together, these considerations led to the Court's conclusion that the procedure for the bond exchange did not violate the applicant's right to nondiscrimination under Article 14 in conjunction with Article $1,1^{\text {st }}$ Protocol of the Convention.

\section{THE FUTURE OF INVOLUNTARY SOVEREIGN DEBT RESTRUCTURINGS}

\section{A. The impact of Mamatas on future involuntary crisis resolution measures}

\section{1) Future crisis resolution measures in the euro area}

All countries in the European Union (EU), including the euro states, are obliged to follow the ECHR, and the outcome of the Mamatas case may therefore affect them. ${ }^{36}$ Below, three core elements of the Mamatas case are discussed in order to shed light on potential future crisis resolution measures in the eurozone.

\section{i) Margin of appreciation}

The Mamatas case reaffirms the practice of the ECtHR with regard to crisis resolution measures adopted after the 2008 financial crisis: states are given a wide margin of appreciation when it comes to determining their social policy, including the adoption of laws intended to balance state income and expenditure, including implementation of involuntary sovereign debt restructurings.

A similar wide margin of appreciation was applied in a recent case in the General Court of the European Union (GC), decided 13 July 2018, Dr K. Chrysostomides \& Co. e.a. v. Council e.a. ${ }^{37}$ The case concerned the financial crisis in Cyprus in 2013, when the governor of the Central Bank of Cyprus placed certain banks into resolution. To implement the bank resolutions, four

\footnotetext{
${ }^{36}$ Though it is not a requirement to incorporate the ECHR into domestic law, it is a prerequisite that all EU members have ratified the convention. See amongst other Vaughne Miller, Is adherence to the European Convention on Human Rights a condition of European Union membership? (Commons Briefing papers SN06577, 2014). Available at http://researchbriefings.parliament.uk/ResearchBriefing/Summary/SN06577

${ }^{37}$ Case T-680/13, Dr K. Chrysostomides \& Co. e.a. v. Council e.a. [2014] OJ C194/25.
} 
decrees were published on the basis of the Law of 22 March $2013 .{ }^{38}$ The decrees caused a substantial reduction in the value of the deposits, shares and bonds of the banks concerned. ${ }^{39}$ The applicants were depositors with or shareholders in these banks. ${ }^{40}$ They claimed that the adoption of the decrees was attributable to various EU institutions (the defendants) ${ }^{41}$ and sought compensation for damage caused by their acts and conduct. More specifically, the applicants claimed they were deprived of their right to property in the deposits they had with the banks concerned and/or in the shares they held in those banks, in breach of Article 17(1) of the Charter of Fundamental Rights of the European Union. This article is to be read in light of both Article $1,1^{\text {st }}$ Protocol to the ECHR, and the case-law of the ECtHR.$^{42}$ In K. Chrysostomides \& Co. e.a. v. Council e.a, the GC specifically referred to the line of argumentation in Mamatas and held that in times of grave economic crisis and to obtain financial stability, eurozone countries are granted a wide margin of appreciation when it comes to implementing crisis resolution measures that interfere with private property, such as reducing the value of deposits, shares and bonds. As in Mamatas, the GC noted that financial crises are complex and that states therefore need to take swift action. Such situations provide only limited time to identify the fairest and most efficient way to distribute burdens amongst the various creditors and investors, and as the GC underlined, the Court will refrain from striking down crisis resolution measures as long as they do not manifestly and gravely disregard the limits of this discretion. Furthermore, the Court held that to conclude that the conduct of the institutions was unlawful when seeking to protect financial stability, it must be established that the limits of the discretion were 'manifestly and gravely disregarded' ${ }^{43}$ This wide margin of appreciation to ensure financial stability provided

\footnotetext{
${ }^{38}$ Case T-680/13, Dr K. Chrysostomides \& Co. e.a. v. Council e.a. [2014] OJ C194/25, § 29-37

${ }^{39}$ Ibid, $\$ 76$

${ }^{40}$ Ibid, $§ 75$

${ }^{41}$ The applicant were seeking compensation for damage allegedly suffered by the applicants as a result of the decision of the Governing Council of the ECB of 21 March 2013, relating to emergency liquidity assistance following a request from the Central Bank of Cyprus; the Euro Group Statements of 25 March, 12 April, 13 May and 13 September 2013 concerning Cyprus; Council Decision 2013/236/EU of 25 April 2013 addressed to Cyprus on specific measures to restore financial stability and sustainable growth; the Memorandum of Understanding of 26 April 2013 on Specific Economic Policy Conditionality concluded between the Republic of Cyprus and the European Stability Mechanism; and other acts and conduct of the Commission, Council, the ECB and the Euro Group connected with the grant of a financial assistance facility to the Republic of Cyprus. See description of the action in the introductory part of Case T-680/13, Dr K. Chrysostomides \& Co. e.a. v. Council e.a. [2014] OJ C194/25.

${ }^{42}$ Charter of Fundamenatl Rights of the European Union [2000] OJ 2000/C 364/01 (18.12.2000). For the purposes of determining the scope of the right to property in the EU Charter, it is necessary, in the light of Article 52(3) of the Charter, to take account of Article 1 of Additional Protocol No 1 to the ECHR. See Case T-680/13, Dr K. Chrysostomides \& Co. e.a. v. Council e.a. [2014] OJ C194/25, §§ 272 and 363.

${ }^{43}$ Ibid, § 291.
} 
for by both the ECtHR and the GC enables states to implement involuntary crisis resolution measures in crisis-struck European countries.

ii) Legitimate expectations, valuation of losses and risk taking

The ECtHR's assessment in Mamatas of the size of the loss for the bondholders concerned may influence future debt crisis measures in the euro area. The Court held that when considering whether a state's interference with the bondholders' property right is proportionate to the aim sought (typically financial stability), the loss incurred should be calculated with reference to the true market value of the investment at the date on which the state adopted the measure (the legislation). It is the market value - not the nominal value - of the bond that represents the profit the investor may legitimately expect, because it takes into consideration the actual risks involved when investing in sovereign bonds. This set of risks includes factors such as the economic circumstances of the issuing country, the possibility that it may default on its payment obligations and the fact that the debtor state may need to restructure its debts. In other words, the investor (the creditor) must also take into consideration, as part of its legitimate expectations, the crisis measures that Greece may take beyond what is agreed upon in the bond contract. ${ }^{44}$ In K. Chrysostomides \& Co. e.a. v. Council e.a, the GC also took up the issue of the valuation of assets that have been subject to an interference for which the owner should be compensated. Regarding securities, and as the ECtHR maintained in Mamatas, the GC stated that 'the amount of the compensation payable is calculated in relation to the true market value of those securities at the time of the adoption of the contested regulation, and not in relation to its nominal value or the amount the owner thereof hoped to receive at the time of its acquisition' ${ }^{45}$ Although this approach - considering the market value when determining to what extent an interference is compensateable - is well established under both the ECHR and European Charter, it is in general not a common approach in sovereign debt disputes. As previously mentioned, sovereign bonds are typically debt instruments issued under and regulated by domestic law and subject to the jurisdiction of domestic courts. Today, the majority of external sovereign bonds are subject to the laws of New York or England. ${ }^{46}$ In these jurisdictions, sovereign debt disputes have generally not focused on questions of the taking of

\footnotetext{
${ }^{44}$ The court held that the loss in nominal value amounting to 53.5 percent could not lead to the conclusion that ECHR Article 1 Protocol No. 1 was violated.

${ }^{45}$ Case T-680/13, Dr K. Chrysostomides \& Co. e.a. v. Council e.a. [2014] OJ C194/25, § 314. See also Mamatas and others $v$ Greece App no 63066/14 (ECHR, 21 July 2016), § 112.

${ }^{46}$ IMF, Strengthening The Contractual Framework to Address Collective Action Problems in Sovereign Debt Restructuring, (IMF Staff Report, 2014) 17.
} 
or interference with property rights (expropriation), but rather on the contractual obligations of the debtor state, that is, whether it has defaulted on its contractual obligations and whether a contractual breach under specific circumstances is excusable.

Simply put, sovereign debt cases in domestic courts typically concern situations in which debtor states, for various reasons, have failed to pay in accordance with the terms of a loan contract. Where there is a lack of payment in violation of the terms, the court will normally quickly establish that there is a breach of contract. When courts thereafter assess what the debtor state is obliged to pay its creditors, a nominalist approach is typically applied. This implies that courts must enforce contractual debt claims in accordance with the actual or presumed intention of the parties, and courts typically apply strict textual interpretation of contracts. Under the principle of nominalism, it is presumed that the parties intend their obligations to be discharged on a 'unit for unit' basis. ${ }^{47}$ When issuing sovereign bonds under New York and English law, sovereign debtors are treated as commercial debtors. There is little room for broader considerations of the complexities of a sovereign default, such as the fact that the debtor is a sovereign state with specific responsibilities towards its citizens and the fact that states are not protected by any domestic or international insolvency law.

By focusing on the market value and thereby also including the inherent risk entailed in investing in securities, the ECtHR and the GC seem to have developed a more nuanced framework. This framework may have a stronger capacity to address problems such as holdout creditors buying debt claims on steep discount to sue for full face value, often disturbing sovereign debt workouts at the cost of the majority of the creditors. ${ }^{48}$ At the same time, the ECtHR's approach in Mamatas can be criticised for granting the state an overly wide margin of appreciation without clarifying any limits to what types of interferences in private property will be accepted in times of economic crisis. The wide margin of appreciation granted to debtor states makes it challenging for creditors to determine whether their expectations are legitimate. Under the ECHR (and the European Charter), lack of predictability for investors concerning the treatment of sovereign debt obligations in the context of economic crisis may also lead creditors to seek protection elsewhere and make the ECHR less relevant in sovereign debt cases. One potential consequence is that there will be instead an increase of sovereign debt cases in

\footnotetext{
${ }^{47}$ Djakhongir Saidov and Ralph Cunnington, Contract damages : domestic and international perspectives (Hart 2008) 646.

${ }^{48}$ See for example NML Capital Ltd. v. Republic of Argentina, No. 08-cv-6978 (S.D.N.Y Dec. 7, 2011).
} 
international investment tribunals, which is also a heavily debated trend, because politicians and academics disagree on whether these tribunals can satisfactorily balance the rights of debtor states and the various creditors in times of economic crisis. It may also lead creditors to push further for sovereign bonds to be issued under and regulated by foreign law - such as that of England or New York - in order to avoid the possibility of unilateral change of the bond terms through an amendment of the background law.

\section{iii) Legislative implementation of class voting in times of CACs}

In Mamatas, the ECtHR expressed general approval of the method applied to restructure the Greek debt: the legislative implementation of a voting procedure in which majority bondholders can bind a dissenting minority. A possible consequence of the Court's support of this type of legislation is that more countries in crisis will implement similar legislation to ease a restructuring.

As mentioned above, the ECtHR did not establish clear limits concerning what types of involuntary measures implemented through legislation would be acceptable. In Mamatas, to substantiate its conclusion that the Greek legislation was proportionate, the ECtHR noted that majority class voting is also a common market tool for enhancing sovereign debt restructuring and is frequently found in sovereign debt contracts in the form of CACs. If such legislation providing for a voting procedure is adopted by other crisis-struck countries, the implementation of a much more radical voting standard than what is commonly found in the market may be more easily struck down by the ECtHR. Bonds issued by euro area states after 1 January 2013 are obliged to carry CACs. It could also be argued that this increases the likelihood that involuntary restructuring based on domestic legislation will be subject to legal challenge. ${ }^{49}$ However, as is discussed in subsection IV B2, the market practice currently varies with regard to the design of CACs. The Greek Bondholder Act set the majority threshold to two-thirds of the face value taking part in the vote. ${ }^{50}$ In general, the Greek law can be said to establish a

\footnotetext{
${ }^{49}$ Buchheit and Gulati, 'Use of the Local Law Advantage in the Restructuring of European Sovereign Bonds' (2018), University of Bologna Law Review, Forthcoming, 5. Available at https://ssrn.com/abstract=3159665.

${ }^{50}$ Zettelmeyer, Trebesch, Gulati, 'The Greek debt restructuring: an autopsy' (2013) 28 Economic Policy 513, 11. The Greek law allowed for a restructuring of domestic-law bonds with the consent of a qualified majority, based on a quorum of votes representing 50 percent of face value. The consent threshold of two-thirds of the face value is related to those taking part in the vote. Importantly, this quorum and threshold applied across the totality of all Greek-law sovereign bonds outstanding, rather than bond-by-bond.
} 
standard that makes it easier to restructure than does the standard under English law bonds ${ }^{51}$, which has become the euro area standard and the standard recommended by the IMF and G20.52

Although the Mamatas judgment took place after the implementation of the euro area CAC became mandatory, the judgment accepted that the Greek legislation implemented a voting threshold lower than that of the euro model CAC. Regardless, it is reasonable to assume that more radical voting standards are more likely to be struck down by the ECtHR. Based on the reasoning in Mamatas, and as long as the market standard varies, it is difficult to set an exact limit.

\section{2) Future Greek crisis resolution measures}

Creditors holding Greek debts may worry that the Mamatas case sends a signal to Greek authorities that involuntary restructurings and haircuts imposed on creditors, or at least enabled by the debtor state unilaterally amending the background law of the loans, represent a legitimate crisis solution measure that may be repeated. However, in the case of Greece, several factors have contributed to decreasing the chances that involuntary restructurings will be implemented in the future.

In the 2012 Greek restructuring process, the bondholders who voluntarily accepted the bond exchange demanded that the new bonds be subject to English law. ${ }^{53}$ Submitting the contract to a law other than that of the issuing state rendered the bonds immune from unilateral changes to the bond terms via the amendment of national legislation. Greece will not therefore be able to implement involuntary debt restructurings in the future. ${ }^{54}$ Furthermore, the new bonds received by the bondholders in exchange for the original bonds now contain CACs. Since CACs enable a qualified majority to amend the bond terms and bind a dissenting minority to a bond exchange, this is likely to improve the chances of a successful restructuring and reduce the need for involuntary debt crisis resolution measures in the future.

\footnotetext{
${ }^{51}$ Ibid, 11 footnote 19.

${ }^{52}$ For further details about the various standards see subsection IV B2.

${ }^{53}$ Branimir Gruić and Philip Wooldridge, 'Enhancements to the BIS debt securities statistics' (2012) BIS Quarterly Review, 67.

${ }^{54}$ It cannot be excluded that Greek authorities will implement other crisis solution measures, which may affect the terms of the bonds indirectly. However, as long as Greece is part of the euro area, it is quite limited in its ability to adjust its monetary policy so as to indirectly influence the debt burden.
} 
Another important influence on the design of potential future crisis measures in Greece is that the country, as a consequence of its debt crisis, lost access to the capital market for a long time. The majority of its recent debt financing stems from official lenders and forms part of the country's debt crisis packages. As of March 2018, Greece's budgetary central government debt $^{55}$ consisted of approximately EUR 344 billion. Of this amount, 19.7 percent was tradable debt, whereas 80.3 percent was nontradable debt. The tradable debt approximately corresponds to bonds and short-term notes, whereas the majority of the nontradable debt consists of financial support mechanism loans from official lenders. ${ }^{56}$ The main contributor has been the European Stability Mechanism (ESM) and the European Financial Stability Facility (EFSF), who have disbursed a total of approximately EUR 204 billion to Greece in official loans. ${ }^{57}$ Official loans and capital raised on the markets, for example through the issuance of bonds, are typically not subject to the same restructuring terms and not restructured at the same time. Official crisis loans to sovereign states, like the ESM loans, are typically entered into by two (or more) subjects of international law and regulated by public international law. These loans, as well as loans offered by public or governmental institutions, are not protected by the ECHR, and Mamatas will therefore not influence the restructuring of the majority of current outstanding Greek loans. ${ }^{58}$ More importantly, Greece cannot unilaterally change the terms of official loan agreements - if they are regulated by international law - through amendment of domestic law. ${ }^{59}$ Involuntary restructuring, that is, unilateral changes to the loan terms through legislation, is

\footnotetext{
${ }^{55}$ According to the IMF, budgetary central government debt consists of 'all outstanding gross liabilities that are debt instruments. A debt instrument is defined as a financial claim that requires payment(s) of interest and/or principal by the debtor to the creditor at a date, or dates, in the future.' See IMF, 'Special Data Dissemination Standard - Greece Central Government Debt', section 2.1.1 < https://dsbb.imf.org/sdds/dqafbase/country/GRC/category/CGD00> accessed 30 August 2018.

${ }^{56}$ Public Debt Management Agency, Hellenic Republic Debt Bulletin, (Bulletin no. 89, 2018), 2. Available at http://www.pdma.gr/attachments/article/1459/Bulletin\%20\%CE\%9D\%CE\%BF_89.pdf. The ESM and EFSF have disbursed a total of $€ 203.77$ billion to Greece. See European Stability Mechanism (ESM), 'Explainer on the final disbursement of ESM financial assistance to Greece and medium-term debt relief measures' (ESM) https://www.esm.europa.eu/content/explainer-final-disbursement-esm-financial-assistance-greece-and-mediumterm-debt-relief accessed 30 August 2018

${ }^{57}$ In June 2018, the Eurogroup approved three medium-term debt relief measures for Greece. Amongst other, it contained further deferral of interest and amortization by 10 years and an extension of the maximum weighted average maturity (WAM) by 10 years on $€ 96.4$ billion of EFSF loans. For details, see European Stability Mechnism (ESM), 'Explainer on the final disbursement of ESM financial assistance to Greece and medium-term debt relief measures' (ESM) https://www.esm.europa.eu/content/explainer-final-disbursement-esm-financial-assistancegreece-and-medium-term-debt-relief accessed 30 August 2018

${ }^{58}$ See Art 34 of the ECHR.

59 The consequences of a default on debt obligations regulated by international law must be assessed under the rules on state responsibility, a question that goes beyond the scope of this article. In practice, however, the consequences of such a default is typically just as much political as they are legal.
} 
possible only in situations in which debt securities are regulated by the law of the debtor country (local law). Hence, these official loans cannot be subject to an involuntary debt restructuring.

\section{B. Existing crisis resolution tools}

\section{1) Involuntary restructurings}

There are no national or international rules regulating sovereign insolvency. As briefly discussed in section II, the starting point is that a debtor state has to renegotiate its debt contracts with its various creditors. Such voluntary renegotiations are challenging, because they easily fall victim to collective action problems, which may effectively hinder a sustainable debt crisis resolution. The result is that debt restructurings have often failed to be sufficiently comprehensive and to bring the debtor country out of its crisis in a sustainable way. Various legal methods and tools exist that may help a debtor country overcome these collective action problems. One such method, though heavily debated, is the implementation of involuntary restructurings, in which the debtor state enables a restructuring agreement by amending its domestic law.

The main argument against such restructuring is that it undermines the fundamental premise that contracts will be enforced as written. Involuntary restructuring that retroactively changes the contract terms, which formed the basis for the creditor's decision to purchase the debt (or enter into the loan agreement) in the first place leads to a lack of predictability for creditors, disturbs the pricing of the capital market and may lead to more expensive loans. ${ }^{60}$

Throughout history, private actors have entered into contracts with states for longer or shorter periods. From time to time, these state contracts were (and still are) called into question by states, and some were even repudiated. Under international law, states are sovereign and free to regulate their internal affairs through legislation; a state may disappoint the expectation of an alien contractor in a number of ways,${ }^{61}$ such as by changing the law regulating the contract. In other words, if the state, through the exercise of its sovereignty, alters the local law to change the terms of the contract in order to ease its obligations, contrary to the original intention of the

\footnotetext{
${ }^{60}$ Buchheit and Gulati, 'Use of the Local Law Advantage in the Restructuring of European Sovereign Bonds' (2018), University of Bologna Law Review, Forthcoming, 5. Available at https://ssrn.com/abstract=3159665. For discussions on the pricing of domestic versus foreign law bonds, See Marcos Chamon, Julian Schumacher, Christoph Trebesch, 'Foreign-law bonds: can they reduce sovereign borrowing costs?', (ECB Working Paper Series, No 2162/ June 2018).

${ }^{61}$ Robert Y Jennings, 'State contracts in international law' (1961) 37 Brit YB Int'l L 156, 156.
} 
contract, then it would not even breach the contract according to the proper law. ${ }^{62}$ It is generally accepted that a new government is not bound to follow the politics of previous governments, and there may be legitimate reasons for changing the background law of a contract. Recent decades have witnessed a rapid growth in both bilateral and multilateral treaties protecting private property of natural and legal persons under a state's jurisdiction as well as foreign investors. Constitutional protection of private property and against retroactive legislation is also widespread. Retroactive legislation interfering with the holding of sovereign debt may of course breach both constitutional law and human rights obligations. ${ }^{63}$ As seen in Mamatas, it is not a black-and-white question, but one that requires careful consideration.

Regardless of legal limitations, concerns that such involuntary restructuring increase legal uncertainty and may lead to higher borrowing costs are very legitimate. There may also be a consensus that involuntary restructurings based on amendment of local law are undesirable, and 'should only be considered as last resort, and even then, only if a crisis erupts before an orderly debt restructuring mechanism can be put in place'. ${ }^{64}$ As Mamatas demonstrated, at least under the ECHR, the state has a wide margin of appreciation to implement crisis resolution measures, also through retroactive legislation. It is difficult to establish exact limits regarding what types of involuntary measures are acceptable.

There are of course a number of legal constraints on implementing involuntary restructurings by means of retroactive legislation, in addition to the ECHR. However, in addition to examining to what extent various rules constrain the implementation of involuntary crisis resolution measures, it is also relevant to ask whether there is a need for involuntary measures to implement sovereign bond restructurings in the future. The answer depends on the degree of effectiveness of the existing framework of sovereign debt restructuring and the existence of alternative tools that may ease the restructuring process.

\footnotetext{
${ }^{62}$ Robert Y Jennings, 'State contracts in international law' (1961) 37 Brit YB Int'l L 156, 157.

${ }^{63}$ It may also violate other obligations, such as investment treaties. For discussions about potential investment protection and sovereign debt, see Michael Waibel, Sovereign defaults before international courts and tribunals (Cambridge University Press 2011).

${ }^{64}$ Buchheit and Gulati, 'Use of the Local Law Advantage in the Restructuring of European Sovereign Bonds' (2018), University of Bologna Law Review, Forthcoming, 5. Available at <https://ssrn.com/abstract=3159665 or http://dx.doi.org/10.2139/ssrn.3159665>
} 
2) $C A C s$

The tool that has gained the most support over the last decade, and that states and international finance institutions mainly rely on to ease sovereign debt restructurings, is the previously mentioned majority voting procedure, which is implemented either by legislation or as a contract clause in the sovereign bonds (CACs). As discussed in section III, this tool enabled Greece to restructure its debts in 2012. Since this time, there has already been an increase in CACs in sovereign bonds in Europe. As of February 2013, it has also become mandatory to implement CACs in euro country sovereign bonds. ${ }^{65}$ It can hence be argued that such legislation will be unnecessary in the future: the inclusion of CACs can decrease the need for state-enforced crisis resolution measures such as unilateral changes to contract terms and makes the question of interference with private property less relevant. Whether there will be a need or wish to implement involuntary restructuring measures by legislation depends on both the effectiveness of current CACs and the prevalence of CACs in outstanding bonds.

\section{i) $\quad \underline{\text { Prevalence }}$}

CACs are not a new phenomenon, not even in sovereign bond contracts, and have traditionally been included in sovereign bonds governed by English and Japanese law. Sovereign debt issuances under New York law, which account for a substantial portion of outstanding sovereign bonds, generally have not included such clauses, because before 2003 amendments to financial terms required unanimous agreement. ${ }^{66}$ In 2003, however, New York shifted away from the unanimity requirement, and there has since been a significant increase in the implementation of CACs. ${ }^{67}$

\footnotetext{
${ }^{65}$ According to art. 12(3) of the Treaty of the European Stability Mechanism, '[c]ollective action clauses shall be included, as of 1 January 2013, in all new euro area government securities, with maturity above one year, in a way which ensure that their legal impact is identical.'. For details about the content of the euro model CAC, see Sub Committee on EU Sovereign Debt Markets, Economic and Financial Committee (EFC), 'Model Collective Action Clause (Common Terms of Reference)' (17 February 2012) $<$ https://treasury.gov.mt/en/Documents/Debt_Management_Directorate/ CACs-Common_Terms_of_Reference/CACs-Text_Model-EN.pdf4> accessed 30 August 2018.

${ }^{66}$ IMF, Strengthening The Contractual Framework to Address Collective Action Problems in Sovereign Debt Restructuring, (IMF Staff Report, 2014) 17. As of 31 October 2016, of the total outstanding stock of international sovereign bonds, approximately 45 per cent is governed by English law and approximately 53 percent by New York law (as a share of nominal principal amount), see IMF, Second Progress Report on Inclusion of enhanced contractual provisions in international sovereign bond contracts, (IMF Policy Paper, 2017) 4 footnote 3.

${ }^{67}$ Anna Gelpern, 'Sovereign Debt: Now What?' (2016), Yale Journal of International Law, Vol. 41, No. 2 - special online edition on Sovereign Debt, 68. Available at SSRN: $\langle$ https://ssrn.com/abstract=2866333 > accessed 30 August 2018.
} 
There is some debate as to why there has been an increase in the implementation of CACs in sovereign bonds. ${ }^{68}$ Some have argued that it is a result of the efforts of the official sector, such as the IMF and G20, pushing for more efficient and sustainable contract practice in sovereign bonds with respect to debt restructurings. Others have claimed that market actors themselves found CACs attractive. Regardless of the origin of the rise of CACs, many have argued that there was momentum for reform of bond contracts to ease the restructuring procedure for sovereign debtors in the aftermath of the IMF's initiative to establish a sovereign debt restructuring mechanism in the early 2000s. The initiative was vetoed by the US, in particular, and the 'softer' and more market-friendly approach, which consisted of promoting the implementation of CACs in sovereign bonds, gained acceptance. Argentina's difficult debt restructuring in 2005 and 2010 and the subsequent years of litigation, brought by the creditors who refused to take part in the restructuring, are also likely to have contributed to the increase in CACs in sovereign bonds. In addition, the fact that the success of the restructuring in Greece was owed to the implementation of CACs may also have contributed to the increased use of this contractual technique.

Today, key international financial institutions, major financial jurisdictions and important market actors see CACs as the main solution to inefficient sovereign debt restructurings. International institutions, such as the International Capital Market Association (ICMA), the IMF and the G20, now recommend that in order to promote a more efficient debt restructuring process, CACs should be implemented in sovereign bonds to stop minority creditors from refusing to participate in debt restructurings that majority creditors find optimal. Since 1 January 2013, it has also become mandatory to implement model CACs in sovereign bonds issued by euro area countries with a maturity over one year. ${ }^{69}$

In older types of CACs, voting is confined to particular series of bonds, which leaves the sovereign vulnerable to individual bondholders with a blocking position within a particular series of bonds. ${ }^{70}$ There is now a broad consensus in favour of CACs that aggregate across series. The ICMA, the IMF and the G20 support the use of these aggregated CACs to ensure

\footnotetext{
${ }^{68}$ See in general W.Mark C.Weidemaier \& Mitu Gulati, 'A people's history of collective action clauses' (2013) 54 VJIL.

${ }^{69}$ Norway does not have CACs in its sovereign bonds. Norwegian bonds are currently subject to the laws of Norway.

${ }^{70}$ International Law Association (ILA), Sovereign Bankruptcy Group, Johannesburg Report 2016 (Biennial Conference - Johannesburg, South Africa 2016) 16.
} 
that holdout creditors cannot block an otherwise efficient restructuring. The euro area model CACs allow for voting across series, but still require a certain (though lower) majority within each series (a two-limb voting procedure). This provides a weaker incentive for creditors to participate in restructuring than the aggregated standard..$^{71}$

CACs clearly do not provide a solution to the problem of minority holdout creditors for outstanding bond debt that does not contain CACs. As of 31 October 2016, the IMF estimated that of the approximately US\$ 1.032 trillion in outstanding foreign law bonds, about 18 percent include aggregated CACs as recommended by the ICMA, the IMF and the G20. Approximately 77 percent of the total outstanding stock of bonds has two-limb aggregated or series-by-series CACs.

Between the end of October 2016 and end of September 2017, the share of international sovereign bonds that include enhanced CACs recommended by the ICMA, the IMF and the G20 grew from 18 percent to 27 percent of total outstanding stock. ${ }^{72}$ These numbers seem encouraging and may indicate that CACs can increase the efficiency of debt restructurings as a crisis resolution measure in the future. The maturity of the outstanding debt also affects the potential efficiency of the CAC. With respect to the maturity profile of the outstanding debt stock that does not contain the enhanced aggregated CACs, approximately 70 percent will mature within the subsequent 10 years, whereas the remaining 30 percent will take 10 years or more to mature. ${ }^{73}$ Of these latter, 68 percent are governed by New York law and may pose a higher risk of holdout behaviour. ${ }^{74}$ Despite a major increase in the implementation of CACs,

\footnotetext{
71 The aggregated standard was suggested by the ICMA after a thorough consultation process including international institutions and market actors. For details on the revised ICMA standard see International Capital Market Association, "Standard Aggregated Collective Action Clauses ("CACs") for the Terms and Conditions of sovereign notes' (2014) https://www.icmagroup.org/assets/documents/Resources/ICMA-Standard-CACsAugust-2014.pdf >. For differences between the ICMA standard and the euro area standard. See Anna Gelpern, 'Sovereign Debt: Now What?' (2016), Yale Journal of International Law, Vol. 41, No. 2 - special online edition on Sovereign Debt, 68. Available at SSRN: <https://ssrn.com/abstract=2866333> and Chanda DeLong, Nikita Aggarwal, 'Strengthening the contractual framework for sovereign debt restructuring — the IMF's perspective' (2016), 11 CMLJ 1.

${ }^{72}$ IMF, Second Progress Report on Inclusion of enhanced contractual provisions in international sovereign bond contracts, (IMF Policy Paper, 2017) 7.

${ }^{73} 48$ percent of the former are below investment grade. IMF, Second Progress Report on Inclusion of enhanced contractual provisions in international sovereign bond contracts, (IMF Policy Paper, 2017) 7.

${ }^{74}$ Ibid 7. New York governed bonds may pose a higher risk as New York court decisions interpreting the pari passu provision in Argentine bonds may strengthen a holdout creditor position in a restructuring. However, the extent to which these decisions will apply to future sovereign bonds is not clear.
} 
there are still (and will be for years to come) substantial numbers of bonds without them. For this stock of debts, there is an increased chance that collective action problems will arise if the sovereign debtor needs to restructure its debts, and there may still be a need for the state to implement mandatory measures against dissenting creditors in order to resolve sovereign debt crises, such as legislative implementation of a CAC with retroactive effects.

ii) The ECB's holding of sovereign bonds

Since the advent of the European financial crisis, the ECB has become a key actor in the euro area's sovereign bonds market. Through the Public Securities Purchase Program (PSPP), the ECB is allowed to purchase sovereign bonds on the secondary market. ${ }^{75}$ The PSPP is part of the Expanded Asset Purchase Programme, a framework programme of the ECB for the purchase of financial assets. The PSPP started in March 2015, and since that time the ECB has been buying, amongst other financial assets, sovereign bonds with the aim of stimulating inflation and growth in the euro area (a strategy often referred to as quantitative easing). ${ }^{76}$ Amounting to EUR 1,534.8 billion as of May 2017, the PSPP accounts for the largest share of the Purchase Programme's total volume of EUR 1,862.1 billion. $^{77}$

The ECB's holdings of sovereign bonds, combined with the increased implementation of CACs in sovereign bonds, presents some new challenges for EU policymakers. It is uncertain whether the ECB's PSPP program and its purchase of sovereign bonds violates EU law. Even assuming that the program as such is legal, ${ }^{78}$ a particular concern is whether the ECB is obliged to vote against a restructuring if a CAC is activated. ${ }^{79}$ The argument is that voting in favour of a

\footnotetext{
${ }^{75}$ Decision (EU) 2015/774 of the European Central Bank in a secondary markets public sector asset purchase program (ECB/2015/10), [2015] OJ L 121/20.

76 For information about ECB's asset purchase program, see in general https://www.ecb.europa.eu/mopo/implement/omt/html/index.en.html\#pspp

77 https://www.bundesverfassungsgericht.de/SharedDocs/Pressemitteilungen/EN/2017/bvg17-070.html

78 In Peter Gauweiler and Others v Deutcher Bundestag (C-62/14) [2015] ECLI:EU:C:2015:400 (not yet published), applicants challenged ECB's outright monetary transaction (OMT) program, another program under which the ECB may purchase sovereign bonds. The ECJ found that OMT program did not violate primary EU law. The OMT program aims at preserving market access for Eurozone sovereign borrowers. Through the OMT, the ECB promises to purchase bonds of distressed Eurozone countries in the secondary market 'in unlimited quantities' if necessary, to ensure continued market access by the debtor country. The program has not yet been implemented, but the mere announcement had, according to the ECB, the wanted effect of calming the market actors. See European Central Bank (ECB), 'More details on the public sector purchase programme (PSPP) Questions \& answers', Press Release (25 January 2015), available at https://www.ecb.europa.eu/press/pr/date/2012/html/pr120906_1.en.html

${ }^{79} 15$ August 2017, the German Federal Constitutional Court referred a several questions to the ECJ for a preliminary ruling, asking them to answer, amongst other, whether the Public Sector Purchase Programme (PSPP) of the European Central Bank (ECB) for the purchase of public sector securities is compatible with Article 123 (1)
} 
restructuring, which will typically entail financial losses, could violate Article 123 (1) TFEU, which prohibits monetary financing of the member states. ${ }^{80}$

In Accorinti and Others $v . \mathrm{ECB},{ }^{81}$ the applicants claimed, that the ECB breached 123 (1) TFEU by concluding the exchange agreement of 15 February 2012 with Greece, which exempted it from partaking in the debt restructuring on the same terms as other bondholders. ${ }^{82}$ The GC rejected the claim and underlined that the exchange agreement was

intended to avoid the involvement of the Eurosystem central banks in the restructuring of the Greek public debt that would mean sacrificing a part of the value of the Greek bonds held in their respective portfolios. However, it should be observed that such unconditional involvement would have been specifically in danger of being classified as intervention having an effect equivalent to that of the direct purchase of state bonds by those central banks, which is prohibited by Art 123 TFEU. ${ }^{83}$

This indicates that the GC may view an ECB vote (or that of another euro area central bank) in favour of a restructuring as a violation of EU law. ${ }^{84}$

The PSPP has an issue share limit, according to which the ECB is barred from purchasing more than $33 \%$ of a euro state's total outstanding government bonds. ${ }^{85}$ This limit must be understood in the context of the mandatory implementation of CACs in the eurozone and the ECB's

and 125 TFEU. The case is still pending. See Bundesverfassungsgericht, 'Proceedings on the European Central Bank's expanded asset purchase programme are stayed - Referral to the Court of Justice of the European Union' (Press Release No. 70/2017, $15 \quad$ August 2017). Available at https://www.bundesverfassungsgericht.de/SharedDocs/Pressemitteilungen/EN/2017/bvg17-070.html.

${ }^{80}$ For a discussion on PSPP and the prohibition against monetary financing, see Grund and Grle, 'The European Central Bank's Public Sector Purchase Programme (PSPP), the Prohibition of Monetary Financing and Sovereign Debt Restructuring Scenarios' (2016) 41 Eur Law Rev 781.

${ }^{81}$ Accorinti and Others $v$ ECB (T-79/13) [2015] ECLI:EU:T:2015:756 (not yet published).

${ }^{82}$ An explicit claim on breach of alleged equal treatment obligations were rejected. See Accorinti and Others $v$ ECB (T-79/13) [2015] ECLI:EU:T:2015:756 (not yet published) §§84-103.

${ }^{83}$ Accorinti and Others v ECB (T-79/13) [2015] ECLI:EU:T:2015:756 (not yet published) $§ 114$.

${ }^{84}$ Accorinti and Others $v$ ECB may seem to contradict the findings in Peter Gauweiler and Others $v$ Deutcher Bundestag (C-62/14) [2015] ECLI:EU:C:2015:400 (not yet published). In Gauweiler, the ECJ concluded that the ECB may accept losses on its bonds to fulfil its mandate. Accorinti, on the other hand, indicate that takin on such losses may violate art. 123 TFEU. For further discussion on ECB and whether a participation in a debt restructuring may violate Art. 123 (1) TFEU, see Grund and Grle, 'The European Central Bank's Public Sector Purchase Programme (PSPP), the Prohibition of Monetary Financing and Sovereign Debt Restructuring Scenarios' (2016) 41 Eur Law Rev 781, in particular page 798-799.

${ }^{85}$ Decision (EU) 2015/774 of the European Central Bank in a secondary markets public sector asset purchase program (ECB/2015/10), [2015] OJ L 121/20. 
approach to avoid holding a blocking position that would stop a restructuring. ${ }^{86}$ Regardless of this limit, the ECB may still hold a significant amount of bonds and only a small number of additional holdout creditors will be needed to actually block a restructuring. An ECB policy of always voting against a restructuring may constitute a significant disrupting element in a crisisstruck country's endeavour to implement resolution measures. By potentially being obliged to vote against all restructurings, the ECB may even undermine its own objectives to sustain stable inflation in the euro area. It also risks undermining the work of the EU concerning the implementation of CACs.

To avoid voting against a restructuring and jeopardising the successful implementation of a crisis resolution measure, the ECB may seek a preferential restructuring deal (or to be exempted from the restructuring), as it did in the Greek restructuring. The same situation was challenged in the Accorinti case, but the GC concluded that the special treatment did not violate EU law. It held that it was justified in providing the ECB with special treatment due to its public role in preserving the common good of the euro area countries and the economy. ${ }^{87}$ Exempting certain creditors from debt restructurings forces the remaining creditors to accept relatively higher haircuts in a restructuring for the debtor country to achieve sustainable debt levels. Providing official sector creditors with noncommercial objectives operating on the bond market with special treatment - even though the bond contains CACs - may disincentivise the remaining bondholders from accepting a restructuring agreement.

To summarise, despite a major increase in the implementation of CACs, there are still (and will be for years to come) substantial numbers of bonds without CACs. The design of CACs actually implemented also varies. The euro CAC has a weaker design than is recommended by the IMF and G20, regarding both the voting threshold and aggregation of voting across series of bonds. Hence, the extent to which a certain CAC can hinder disruptive holdout creditors from blocking a restructuring attempt will vary. Moreover, the official sector creditors' purchasing of sovereign bonds on the secondary market, for various reasons, further complicates sovereign bond restructurings. The ECB may be forced, in order not to violate primary EU law, to vote against a debt restructuring. It would thereby complicate the restructuring process, either by

\footnotetext{
${ }^{86}$ Grund and Grle, 'The European Central Bank's Public Sector Purchase Programme (PSPP), the Prohibition of Monetary Financing and Sovereign Debt Restructuring Scenarios' (2016) 41 Eur Law Rev 781, 782.

${ }^{87}$ Though there is nothing in EU law saying that creditors holding the same bond should be treated equal, contractual provisions such as the pari passu clause, may inhibit preferential agreements.
} 
being a holdout creditor or by forcing the debtor country to grant it special treatment. CACs are therefore only partially able to provide for a solution to the collective action problems in eurozone debt restructurings, and there may still be a need for the state to implement involuntary measures against creditors in order to resolve sovereign debt crises.

\section{3) Systemic limitations and policy options}

i) Limitation of involuntary measures

In situations where CACs fail to solve collective action problems and to sufficiently ease the restructuring process, the debtor state's main alternative tool is to implement involuntary restructuring measures. ${ }^{88}$ However, involuntary debt restructurings also have their limitations. First, involuntary debt restructurings are possible only for debt regulated by the laws of the debtor country. Legislation by national parliaments has no authority beyond domestic borders and is therefore unable to alter foreign-law debt or international law debt. In EU countries, the majority of bonds issued are regulated by domestic law ${ }^{89}$ and may hence be restructured by involuntary means if this approach is deemed necessary. To ensure that the majority of the creditors would accept the 2012 Greek restructuring, Greece had to accept that the restructured bonds were regulated by foreign law. Consequently, the new bonds were immune from future involuntary restructuring based on amendment of legislation. There was a tradeoff for Greece, because the country is prevented from implementing similar kinds of involuntary measures in the future. Greece is now fully dependent on the majority voting provision adopted by law, or voluntary agreements, in potential future debt restructurings. The Greek experience indicates that, at least if a restructuring is implemented by a majority vote, the local-law-amendment approach may be a onetime possibility, because the bondholders can later require that new bonds are regulated by foreign law. ${ }^{90}$ Moreover, the various euro countries have their own

\footnotetext{
${ }^{88}$ Exit consent is an alternative tool, though less used since the implementation of CACs. On exit consent, see for example Rodrigo Olivares-Caminal, Legal aspects of sovereign debt restructuring (Sweet \& Maxwell, 2009) 118-126.

${ }^{89}$ Marcos Chamon, Julian Schumacher, Christoph Trebesch, 'Foreign-law bonds: can they reduce sovereign borrowing costs?', (ECB Working Paper Series, No 2162/ June 2018) figure at page 6. Available at https://www.ecb.europa.eu/pub/pdf/scpwps/ecb.wp2162.en.pdf

${ }^{90}$ Buchheit and Gulati, 'Use of the Local Law Advantage in the Restructuring of European Sovereign Bonds' (2018), University of Bologna Law Review, Forthcoming, 5. Available at https://ssrn.com/abstract=3159665 or http://dx.doi.org/10.2139/ssrn.3159665. See also Marcos Chamon, Julian Schumacher, Christoph Trebesch, 'Foreign-law bonds: can they reduce sovereign borrowing costs?', (ECB Working Paper Series, No 2162/ June 2018). Available at https://www.ecb.europa.eu/pub/pdf/scpwps/ecb.wp2162.en.pdf, 2. In the latter article, the authors find that a foreign-law premium exists, but it only becomes sizable and relevant in periods of debt distress. During non-crisis times and in less vulnerable countries, however, the authors find that the premium can be slightly
} 
constitutional constraints concerning the possibility for the government to interfere with private property. Not all constitutions are as flexible as the Greek, which allowed for the retroactive legislation. ${ }^{91}$ This increases the uncertainty about whether involuntary restructuring will be a sustainable method for dealing with sovereign debt crises.

ii) $\quad \underline{\text { Official sector bailout }}$

Restructuring debt is one way to solve a state's debt problems. A state can also seek to obtain official crisis loans, or to implement only austerity measures and structural reforms, in order to make its way out of a crisis.

Since 2010, the eurozone actors' approach to crisis resolution has exhibited a clear tendency to lend crisis-struck countries the money they need for timely repayment of all their outstanding debt obligations..$^{92}$ Greece's 2012 restructuring is the main exception to this tendency. It is uncertain to what extent the EU (and its member states) is financially able and politically willing to bail out bigger economies, such as Italy, in a future debt crisis. ${ }^{93}$ There is an ongoing discussion concerning a larger euro area reform. ${ }^{94}$ This article touches upon a limited part of this debate by addressing whether the existing crisis resolution tools make restructuring a viable alternative to official crisis loans.

The previous sections have argued that CACs have limitations and are unable to ensure successful restructurings under all circumstances, which increases the chances that crisis-struck countries will implement involuntary debt restructurings. Moreover, such involuntary measures are only partly able to provide for a sustainable debt restructuring and are broadly disliked, because they interfere in contract rights in an unpredictable manner. This indicates that there is a need to further ease the restructuring process. If the euro area wants to make sovereign debt restructuring a viable option in times of crisis, there is a need for new legal tools or an improvement of existing crisis resolution tools.

\footnotetext{
negative, implying that governments incur a small cost when issuing foreign-law bonds outside of distress episodes.

${ }^{91}$ Buchheit and Gulati, 'Use of the Local Law Advantage in the Restructuring of European Sovereign Bonds' (2018), University of Bologna Law Review, Forthcoming, 5. Available at https://ssrn.com/abstract=3159665 or http://dx.doi.org/10.2139/ssrn.3159665

${ }^{92}$ See for example See for Lee C. Buchheit and G. Mitu Gulati, 'Sovereign Debt Restructuring in Europe' (2018), 9 Global Policy, 65.

${ }^{93}$ Ibid, 65.

${ }^{94}$ See for example CEPR Policy Portal for research based policy analysis and commentary from leading economists: https://voxeu.org/debates/euro-area-reform
} 


\section{Global discussions of sovereign debt crisis resolution reforms}

The challenges related to sovereign debt crisis resolution have also been discussed at the international level, and there is broad agreement concerning the need to improve the current system. In particular, the discussion has focused on sovereign debt restructuring for central government debt, because such restructurings often suffer from the problem of 'too little (debt), too late' and hence fail to achieve lasting debt sustainability. ${ }^{95}$ No corresponding agreement exists regarding the means that should be used to solve the challenges of the system of debt restructuring. The reform debate is politicised and polarised. On one side are advocates for statutory reform, who demand the establishment of international binding rules and a sovereign restructuring forum; on the other are advocates for market-based contractual reform, who rely primarily on the implementation of aggregated CACs to solve restructuring problems. The latter group is unwilling to pursue reforms that are more comprehensive, because they believe these will increase moral hazards (by making it too easy for sovereign debtors to restructure) and lending costs. ${ }^{96}$

This polarised opposition materialised in part during a recent attempt to improve the current system of sovereign debt crisis resolution. In September 2015, the United Nations General Assembly adopted a resolution on the basic principles for sovereign debt restructuring (hereafter 'UN Principles'). ${ }^{97}$ The resolution acknowledged the inefficiencies of the current system of sovereign debt restructuring and in particular the need to deal with coordination problems amongst creditors. The UN Principles state that sovereign debt restructuring processes should be guided by the principles of sovereignty, good faith, transparency, impartiality, equitable treatment, sovereign immunity, legitimacy, sustainability and majority restructuring. The objective of the Principles is to balance the rights of the creditors with the need for the debtor state to achieve debt sustainability by efficiently minimising the losses for all parties involved. ${ }^{98}$ The vote in the General Assembly concerned soft law principles rather than a binding treaty or the establishment of court-like institutions. The Principles hardly

\footnotetext{
${ }^{95}$ IMF, Sovereign Debt Restructuring - Recent Developments and Implications for the Fund's Legal and Policy Framework, (IMF Staff Report, 2013) 15.

${ }^{96}$ Anna Gelpern, 'Sovereign Debt: Now What?' (2016), Yale Journal of International Law, Vol. 41, No. 2 special online edition on Sovereign Debt, 85. Available at SSRN: 〈https://ssrn.com/abstract=2866333 >

${ }^{97}$ General Assembly Resolution 69/319 (2015).

${ }^{98}$ See in general Yale Journal of International Law, Vol. 41, No. 2 - special online edition, 2016 for discussions on reform of the current system of sovereign debt restructuring, including how the UN principles can contribute to this.
} 
espoused the more radical suggestions put forward by those in favour of comprehensive sovereign restructuring reforms. Nevertheless, they failed to please all parties, precisely because they went beyond a contractual approach. The great majority of the General Assembly, 183 countries, acknowledged the need for broader reform - in addition to contractual reforms such as the implementation of CACs - and voted in favour of adopting the Principles. However, a number of influential developed countries were reluctant to take this route: 41 countries abstained, and six countries voted against. The countries voting against were Canada, Germany, Israel, Japan, the UK and the US. ${ }^{99}$ All these countries represent jurisdictions of financial importance, and the majority of international sovereign bonds are subject to the laws of one of these jurisdictions. In this politically polarised context, a sudden shift towards a framework of more comprehensive insolvency reform for sovereign debt seems unfeasible. ${ }^{100}$

\section{CONCLUDING REMARKS}

Mamatas is a key case - and one of very few - in which the ECtHR has dealt with sovereign debt. It provides for a good illustration of the legal points of departure for assessing the validity under the ECHR of a state's forcible measures, including the validity of involuntary debt restructurings in times of grave economic crisis. The case sets out a number of legal starting points when considering which involuntary crisis measures interfering with the right to private property will be regarded as proportionate under the ECHR.

The case first reaffirms the practice of the Court in relation to post-2008 crisis resolution measures, which gives states a wide margin of appreciation when it comes to determining their social policy, including the adoption of laws that aim to balance the state's revenue and expenditure. Second, Mamatas makes it clear that when considering whether a state's interference with the bondholders' property right is proportionate to the aim sought, the loss incurred should be calculated with reference to the true market value of the investment. The ECtHR holds that the market value represents the profit that an investor may legitimately expect, implying that an investor has to take into consideration factors such as the economic circumstances of the issuing country, the possibility that it may default on its payments obligations and the fact that the debtor state may need to restructure its debts. Third, the ECtHR

\footnotetext{
${ }^{99}$ See Martin Guzmanm M. and Joseph E. Stiglitz, A Soft Law Mechanism for Sovereign Debt Restructuring Based on the UN Principles (Friedrich Ebert Stiftung 2016) 4 <http://library.fes.de/pdf-files/iez/12873.pdf>

${ }^{100}$ Anna Gelpern, 'Sovereign Debt: Now What?' (2016), Yale Journal of International Law, Vol. 41, No. 2 special online edition on Sovereign Debt, 85. Available at SSRN: <https://ssrn.com/abstract=2866333>
} 
accepted the Greek crisis resolution measure, in which a class voting procedure in which majority bondholders could bind dissenting minorities was implemented through legislation. The court's support of this type of legislation - which function is the same as CACs found in sovereign bond terms - may inspire other crisis-struck countries to follow Greece's example.

This article argues that CACs have limitations as a crisis resolution tool, both due to its prevalence and design. Hence, and despite it being a debated crisis resolution tool, there may still be a need for the state to implement other involuntary measures against creditors in order to resolve sovereign debt crises.

As Mamatas has demonstrated, at least under the ECHR, the state has a wide margin of appreciation for implementing crisis resolution measures, including the use of retroactive legislation. The wide margin of appreciation creates a lack of predictability for creditors with respect to their rights in sovereign debt instruments under the ECHR, which may lead them to seek protection elsewhere, for example in international investment tribunals.

Relying on involuntary measures based on changing local law as a crisis resolution tool also has its limitations, in particular because it is applicable only to debts regulated by the law of the debtor country and because markets may pressure sovereign debtors to issue under foreign law if the debtor state has previously applied involuntary restructuring measures.

Restructuring debt is one way of solving a state's debt problems. A state can also seek to obtain official crisis loans, or implement austerity measures and structural reforms, to make its way out of a crisis. Both CACs and involuntary debt restructuring based on amendments of the law of the debtor state are tools for overcoming collective action problems and easing sovereign debt restructuring. However, both tools have limitations. Opponents of involuntary restructuring and those who view it as a legitimate and useful crisis resolution tool would agree that there is a need for further reform if restructuring is to remain a viable crisis resolution option. 